\title{
introducing a philosophical discussion in your classroom: an example of a community of enquiry in a greek primary $\operatorname{school}^{1}$
}

\author{
ourania maria ventista ${ }^{2}$ \\ durham university, uk \\ marita paparoussi ${ }^{3}$ \\ university of thessaly, greece
}

abstract

Philosophy for Children (P4C) is implemented in different countries, but there are not many studies which examine P4C in Greek primary schools. This research examines a P4C intervention in a primary school in northern Greece. This study can be used as a guide for educators who are interested in starting implementing $\mathrm{P} 4 \mathrm{C}$, because it describes the structure of the initial $\mathrm{P} 4 \mathrm{C}$ session in an untrained classroom and it provides an analysis of easily implemented formative assessment practices. The research questions are similar to the questions that educators could set when they initially implement P4C: Do the students raise philosophical questions? Are the students engaged in the dialogue? Do students provide concrete reasons to support their opinions? Are students willing to listen to the different opinions of their classmates? Do they enjoy participating in the sessions? Does P4C intervention have an impact on the students' opinion concerning the discussed topic after the intervention? The conducted research used Shel Silverstein's, The Missing Piece Meets the Big O (1976/ 2006) as an introductory stimulus. The participants were twenty Year 6 students. The research design is experimental with pre-testing and posttesting of the students' opinion about fulfilment before and after the sessions. The findings cannot be generalized, but they clearly demonstrate that the participating students wonder about philosophical issues and they developed a dialogue on fulfilment. All the students in our sample were engaged in this dialogue and the post-tests showed a modification in the expressed opinion after P4C sessions.

keywords: philosophy for children; primary school; Greece; formative assessment.

\section{introduciendo la discusión filosófica en su aula: un ejemplo de comunidad de investigación en una escuela primaria griega}

resumen

Filosofía para Niños (FpN) está implementada en distintos países, pero no hay muchos estudios que examinan $\mathrm{FpN}$ en las escuelas primarias de Grecia. Esta investigación examina una intervención de $\mathrm{FpN}$ en una escuela primaria del norte de Grecia. Este estudio puede ser usado como una guía para educadores que están interesados en comenzar a implementar $\mathrm{FpN}$, porque describe la estructura del inicio de una sesión de $\mathrm{FpN}$ en una clase sin experiencia y provee un análisis de las prácticas de evaluación formativa fácilmente implementadas. Las preguntas de esta investigación son similares a las preguntas que los educadores pueden hacerse cuando inician la implementación de FpN: ¿Los estudiantes plantean preguntas filosóficas? ¿Los estudiantes están involucrados

\footnotetext{
${ }^{1}$ We would like to express our deep gratitude to Prof Stephen Gorard, Dr Nadia Siddiqui and Mr Steve Williams for their comments which greatly improved the manuscript.

2 E-mail: o.m.ventista@durham.ac.uk

3 E-mail: mpaparou@uth.gr
} 
introducing a philosophical discussion in your classroom: an example of a community of enquiry in a greek primary school

en el diálogo? ¿Los estudiantes dan razones concretas para sostener sus opiniones? ¿Los estudiantes están dispuestos a escuchar a las diferentes opiniones de sus compañeros de clase? ¿Disfrutan de participar en las sesiones? ¿La intervención de FpN tiene impacto en la opinión de los estudiantes sobre el tema discutido después de la intervención? Dicha investigación utilizó la obra de Shel Silverstein, The Missing Piece Meets the Big O (1976/2006) como estímulo introductorio. Eran veinte participantes de 6 años de edad. El proyecto de investigación es experimental con pruebas de opinión de los alumnos, realizados antes y después de las sesiones. Los resultados no pueden ser generalizados, pero demuestran claramente que los alumnos participantes se preguntan sobre cuestiones filosóficas y desarrollan un diálogo satisfactoriamente. Todos los alumnos de nuestra muestra participaron de dicho diálogo y las pruebas posteriores evidencian un cambio en la opinión expresada después de las sesiones de FpN.

palabras clave: filosofía para niños; escuela primaria; Grecia; evaluación formativa.

\section{introduzindo a discussão filosófica na sua sala de aula: um exemplo de comunidade de investigação em uma escola primária grega}

resumo

Filosofia para Crianças $(\mathrm{FpC})$ foi implementado em diferentes países, mas não há muitos estudos que examinam $\mathrm{FpC}$ nas escolas primárias gregas. Essa pesquisa investiga a intervenção de $\mathrm{FpC}$ em uma escola primária no norte da Grécia. Esse estudo pode ser usado como um roteiro para educadores interessados em começar a implementar FpC, porque descreve a estrutura de uma sessão inicial de FpC em uma sala de aula inexperiente e proporciona uma análise de práticas de avaliação formativa facilmente implementadas. As perguntas da pesquisa são similares às perguntas que os educadores podem fazer quando estão iniciando a implementação da FpC: Os estudantes levantam questões filosóficas? Os estudantes estão envolvidos no diálogo? Os estudantes fornecem razões concretas para apoiar suas opiniões? Os estudantes estão dispostos a ouvir as opiniões diferentes de seus colegas de classe? Eles gostam de participar das sessões? A intervenção da $\mathrm{FpC}$ tem impacto na opinião dos alunos sobre o tema discutido após a intervenção? A pesquisa conduzida utilizou Shel Silverstein, The Missing Piece Meets the Big O (1976/2006) como estímulo introdutório. Os participantes eram vinte estudantes de 6 anos. O projeto de pesquisa é experimental com testes de opinião dos alunos realizados antes e após as sessões. Os resultados não podem ser generalizados, mas eles demonstram claramente que os alunos participantes se fazem perguntas filosóficas e desenvolveram satisfatoriamente um diálogo. Todos os alunos da nossa amostra participaram deste diálogo e os testes posteriores mostraram uma modificação na opinião expressa após as sessões FpC.

palavras-chave: filosofia para crianças; escola primária; Grécia; avaliação formativa. 
introducing a philosophical discussion in your classroom: an example of a community of enquiry in a greek primary school

Children's ability to philosophise has been widely questioned over the last decades. It has been argued that 'real' philosophy can be done solely by adults because philosophy demands mental maturity, knowledge, and 'higher-order thinking' (KITCHENER, 1990, p. 422) -characteristics that children might not have. As logical as this view seems, however, one ought to question the meaning of the term 'real' philosophy. Indeed a difficult subject to define, our working definition of philosophy is 'an activity of thought which systematically explores basic assumptions, ideas, and beliefs'. Philosophy, in simple terms, is about making sense of what there is. It is a discipline concerned with 'fundamental questions'; 'questions which increase the interest of the world, and show the strangeness and wonder lying just below the surface even in the commonest things of daily life' (RUSSELL 1959, p. 16) -making philosophy an essential part of the activities of both intellectual and emotional growth. Furthermore, philosophy is associated with the principles that underlie the human existence and it cannot be restricted merely to mental maturity and higher-order thinking. Viewing philosophy in this way, the question should not be "whether children can do philosophy?", but "how philosophy can be taught and practised most effectively in education?"

Primary school philosophy education, therefore, is about giving children the opportunity to explore fundamental aspects of their experiences that are already meaningful for them, in order to become more sensitive to their philosophical dimensions (ethical, logical, metaphysical, epistemological). It is also about developing the ability to question; to formulate an argument; to wonder about things that are taken for granted; to appreciate the views of others; and, to be able to work collaboratively. Matthew Lipman, the Philosophy for Children

\footnotetext{
${ }^{4}$ Matthew Lipman was the first to write novels in order to introduce philosophical thinking to children. The protagonists of the novels are children raising philosophical problems and engaging in philosophical dialogue. Karin Murris and Joanna Haynes prefer doing philosophy with picture books because pictures parallel to the narrative invite an intellectual and an emotional response which enables children to make meaning for themselves in a playful and imaginative manner. As
} 
introducing a philosophical discussion in your classroom: an example of a community of enquiry in a greek primary school

$(\mathrm{P} 4 \mathrm{C})^{5}$ pioneer, summarizes the point well when explains that Philosophy for Children encourages students to think critically, creatively, and caringly (LIPMAN, 2003).

The central aim of $\mathrm{P} 4 \mathrm{C}$ is to help children develop their thinking for themselves and their thinking in a community. Our work draws its theoretical inspiration from this body of work. To be more precise, our views are in accordance with the work of P4C tradition, as well as on the work of 'secondgeneration' P4C proponents, especially those who argue the value of using children's literature as a stimulus for philosophical discussion in the primary school because it explores topics which can catch children's interest in issues related to their own life (HAYNES, 2008; MURRIS, 1992). We understand P4C as a movement that promotes a forum for discussions in which children are encouraged to think and reflect together, to justify their beliefs and ideas, to develop appropriate language for a dialogue and argumentation, and to become aware of their capacity for discussion. Here, a crucial point to consider is that P4C involves the engagement of students in a philosophical Community of Enquiry and highlights the dialogical character of enquiry and the primacy of questioning. ${ }^{2}$ As Lipman noted: "[...] In any event, this recognition of the elevated status of the question (and the reduced status of the answer) will help the students remember that questioning is the leading edge of inquiry; it opens the door to dialogue, to self-criticism, and to self-correction" (LIPMAN, 2009, p. 32). In line with Lipman's emphasis on the primacy of questioning, we view literature as being central to the philosophical community's discussions in the sense that asking questions is a spontaneous response to literary texts that offer the reader thoughts to reflect on, new perspectives to consider, and assumptions to verify. Literary texts explore

they point out in Picturebooks, Pedagogy, and Philosophy, "Literature that contains both the everyday and the strange and unfamiliar mediates philosophical understanding. Philosophical enquiry requires delicate facilitation between the abstract and the concrete, otherwise learners and teachers lose themselves in meaningless abstraction" (HAYNES; MURRIS, 2012, p. 62).

${ }^{5} \mathrm{P} 4 \mathrm{C}$ recommends the engagement of students in a philosophical Community of Enquiry, in which "students listen to each other with respect, build on one another's ideas, challenge one another to supply reasons for otherwise unsupported opinions, assist each other in drawing inferences from what has been said, and seek to identify one another's assumptions" (LIPMAN, 2003, p. 18). 
issues that matter to us as human beings and as they present 'gaps' and indeterminacies that offer the opportunity for discussions of multiple alternative interpretations, they can influence readers into cultivating their interest in questions rather than answers. As Hilary Putnam asserts in Meaning and the Moral Sciences (talking more specifically about moral philosophy): 'Literature does not, or does not often, depict solutions. What especially the novel does is aid us in the imaginative re-creation of moral perplexities, in the widest sense' (PUTNAM, 1978, p. 86).

\section{research questions and research design}

In Greece philosophy is taught only one year in the secondary school as an optional module and it is not included in the national curriculum of primary education. Moreover, while in many other countries there are organisations, such as SAPERE in the UK (SAPERE, 2015), which provide different levels of P4C training, in Greece there is no provision for this training. Therefore, it is particularly interesting to investigate the topic in Greek context, because P4C does not have the tradition and the development that it has in other countries. This research can be a guide for Greek educators, and any educator in general, who are not trained in $\mathrm{P} 4 \mathrm{C}$ but interested in implementing $\mathrm{P} 4 \mathrm{C}$ in the classroom and assessing its implementation.

Our sessions have two main differences compared to Lipman's suggestions for a dialogue in a community of enquiry; the structured lesson plan and the introductory stimulus for the dialogue. Firstly, our P4C session structure is based on the lesson plans suggested by Wartenberg (2009). In his book Big Ideas for Little Kids, he proposes a curriculum for P4C for teachers who are interested in teaching through P4C method in elementary schools. As he dispels; 'You don't have to know any philosophy to teach it!' (2009, p. 8). Maybe claiming that 'any' philosophy is enough to teach $\mathrm{P} 4 \mathrm{C}$ is problematic, but we also support that educators do not have to be philosophers to teach philosophy in primary schools. According to Watenberg (2009) lesson plans, the dialogue is guided by the 
introducing a philosophical discussion in your classroom: an example of a community of enquiry in a greek primary school

comments of students, but the teacher is prepared and has pre-decided some leading questions deriving from the main topic of the book presented.

Secondly, this research does not use a novel written by Lipman. When Lipman (1992, p. 4) discusses his first novel Harry Stottlemeier, he mentions that what distinguishes each character in the book from another was their styles of thinking. Similarly, we used the book of Silverstein The Missing Piece Meets the Big $O(1976 / 2006)$ in which the characters are distinguished from each other according to their different approach to achieve fulfilment. Harry Stottlemeier can stimulate discussion on thinking and The Missing Piece Meets the Big $O$ can be used as a stimulus to trigger philosophical discussion on the individual's responsibility to achieve fulfilment. This book presents the effort of the genderless character 'Missing Piece' to be fulfilled. While (s)he tries to roll by trying to fit with other characters, (s)he meets Big O who encourages him/her to roll by itself.

After presenting the two main discrepancies between our sessions and sessions which follow Lipman's tradition, it is meaningful for the research questions to be cited. The research questions that we used could be similar to the questions that a teacher would have set when they initially start P4C. Sharp (1992) also recommends the novice teacher to contemplate on similar questions after one month of implementation of P4C. Specifically, our research questions were:

- Do students contemplate philosophical issues?

- Are the students engaged in the community of enquiry?

- Do students enjoy P4C sessions and what improvements do they suggest?

- Can P4C sessions cause a change in the students' opinion on a topic? It is important to clarify that change is referring to a temporary change and without knowing whether this change has an impact on the actions of students or not.

The last of these questions is a causal question. For this reason, experimental research design was used. Specifically, the design consisted of an exploration of the preconceived notions of students about fulfilment and an 
assessment at the end without a control group (Mertens, 2010). Using the way that Gorard (2013) suggests for the presentation of such type of research, our research could be presented as:
$\mathrm{O}_{1}$
$X$
$\mathrm{O}_{2}$
$\mathrm{O}_{1}$ is the pre-test
$\mathrm{X}$ is the intervention $=$ the $4 \mathrm{P} 4 \mathrm{C}$ sessions
$\mathrm{O}_{2}$ is the post-test

For the first three research questions we collected data during and after the sessions.

\section{measurement tools}

In this section, the measurement tools to answer our research questions are described. These tools, however, can be easily used by educators to evaluate the P4C sessions in their classrooms. Wartenberg $(2009$, p. 18) supports that the dialogue itself could prove the success of the P4C sessions. In a later stage, he admits that there are internal and external reasons to evaluate the programme and search for evidence for P4C effectiveness (WARTENBERG, 2014). It is useful for the educators to use some plain formative assessment techniques. These tools help them get feedback about the sessions, identify deficiencies, improve the implementation and possibly increase the engagement of students.

Firstly, in order for the construct of engagement to be measured, it should be operationalized (STEVENS, 1935). For its operationalization indicators which can be identified in a community of enquiry were used; the participation in the discussion, the use of justification, the questioning, the attempt to define concepts or set criteria. To investigate students' enjoyment for participating in a community of enquiry, the students completed a questionnaire at the end of the process. The students had to specify what they enjoyed the most, suggest a topic for a potential next session and make recommendations for improvement. The topics suggested 
introducing a philosophical discussion in your classroom: an example of a community of enquiry in a greek primary school

and the questions set during the sessions revealed whether there are philosophical issues that students contemplate.

With regard to the causal question, whether the P4C can cause even a temporary change in the expressed opinion of the students, a pre-test and a posttest were implemented. To set it more precisely, at the beginning of the process the students completed a test which asked them to write what the main characteristic of a fantastic character called $\mathrm{Mr}$ Complete. Moreover, they were offered also the opportunity to draw Mr Complete. This exercise was used as a pre-test to identify the pre-conceptions of the students about fulfilment. After the four sessions, the students were also asked to write what fulfilment is. The answers in the post-tests were not matched to the prior performance of each student because they were anonymous. The reason why anonymous assessment was selected for this research is that we did not intend to give the impression to the students that their individual performance will have consequences, such as obtaining a good mark. The assessment was solely aiming at the exploration of the effectiveness of the P4C sessions. The students' replies were evaluated based on their length and their elaboration.

\section{sample}

The sample for this research was chosen with a convenience sampling method (COHEN; MANION; MORRISON, 2007) based on the willingness of the head teacher to participate in the research. This research took place in a Year 6 classroom in a school in the Northern Greece. Specifically, the selected school is located in a suburban area on the mainland of Greece and the majority of the students have a middle socio-economic background. In the classroom, there were 20 students (11 males and 9 females). The participants did not have any previous experience of participating in a community of enquiry.

\section{P4C sessions}

Wartenberg (2009, p. 41) suggests in the first session to post a list of rules in the classroom. Wartenberg describes this process as an announcement of the 
rules of a P4C session decided by the teacher and communicated to the students. Fisher (2003, p. 62) suggests in Teaching Thinking that it is important to establish the ground 'rules' for effective discussion. According to Fisher's approach, this is a collaborative process, guided by the students. In a similar vein, we asked students to propose their 'principles' for a successful dialogue. We intentionally avoided the use of the term 'rule', because it could be perceived as authoritative. It is worth noting that the proposed principles are in line with the commonly used P4C principles. The only principle that the participating students did not think of suggesting is "We try to give reasons for what we say". Even though justifying the presented opinions is an essential principle for $\mathrm{P} 4 \mathrm{C}$, the students did not propose it. However, they were facilitated to articulate it. The principles were written on a cardboard and they were posted on a wall in the classroom to be visible. Students could refer to them if needed. It was explicitly mentioned that the students could add or modify the principles during the process. In this research, there was no modification or addition of the principles. The explanation of this could be that the research was short-term so that the students did not have enough time to identify weaknesses or omissions in the decided conventions. The final principles were;

- 'We should talk only when it's our turn'

- $\quad$ 'Let's try to listen what our classmate has to say'

- 'We should respect our classmates and their opinion'

- 'We should not speak over one another'

- 'Even if we disagree, we should let the other person complete his/her speech'

- 'We should freely express our opinion'

- 'We should justify what we say'

Then the book of Silverstein was read twice; once by the teacher-researcher and once by a student. At the same time, the pictures of the book were projected on the classroom's wall, so all the students could see them. After reading, the students should be required to question on the text and then vote on the question to be discussed in that session (FISHER, 2003). Kennedy (2004) suggests that the teacher 
introducing a philosophical discussion in your classroom: an example of a community of enquiry in a greek primary school

as a facilitator cannot pre-decide or control where the dialogue will lead and he discusses some similarities between the role of teacher proposed by Freire and the role of facilitator in a community of enquiry. The teacher-researcher as a facilitator is suggested to summarise statements and he helps the students to discuss the consequences and the assumptions of their statements (KENNEDY, 2004, p. 758). The teacher-researcher had this role. Nevertheless, due to the fact that the students were not familiar with $\mathrm{P} 4 \mathrm{C}$, the teacher-researcher initiated the discussion by asking questions in a more structured setting and every time the discussion would stagnate the researcher introduced a new theme or aspect. The discussion can be summarised as having six main themes:

- The identification with a character and the reason for this identification

- The reasons why someone might feel as a Missing Piece

- What somebody can do in order not to feel like a Missing Piece

- Ways that someone has to complete themselves

- $\quad$ Reasons why two people might not complete each other even though they previously did

- Whether acquiring completeness can be achieved or it is just a neverending process

During this intervention, the teacher-researcher facilitated the dialogue, but the students' replies and comments guided the dialogue. It is essential to be clarified that the extent to which educators intervene should not be pre-decided. It should be dependent on the needs of the specific classroom and context. For example, students who are not trained in P4C or a dialogue on a sensitive topic would possibly require more guidance from the educator. What is more, the facilitators of a dialogue in a community of enquiry should always understand that each time they intervene the dialogue is slightly transformed (KENNEDY, 2004, p. 761). As any intervention can cause a change, the facilitator should wisely choose when and how to play a role in the dialogue. This is the reason why it is crucial for the community of enquiry to be facilitated by teachers who do not just have 
knowledge, but they also practice and hold a deep understanding of principles of liberal education.

results

Do students contemplate philosophical issues?

P4C sessions are based on dialogue. Students can engage in dialogue, but they yet can potentially not contemplate philosophical questions. According to Wartenberg's lesson plans (2009), there are questions pre-decided by teachers. Teachers choose the questions according to the main topic of the book. Nevertheless, it is interesting to investigate whether students ponder philosophical questions. We asked the students in our sample to suggest topics for a future $\mathrm{P} 4 \mathrm{C}$ session. The topics which arose were:

- $\quad$ the creation of the world

- $\quad$ the creation of man

- $\quad$ the end of the world

- the advantages and the disadvantages of the being a human

- where do we go when we die

The majority of these questions could be categorised as questions that raise metaphysical inquiries. It could be argued that the question concerning the creation of the world could be classified as epistemological. Nevertheless, the way in which questions were phrased suggests a metaphysical concern. Solely the questions regarding the human nature could be categorised as a question of ethics. This finding can be associated with what Lipman (1988, p. 195) said: 'Why do they (the children) ask so many metaphysical questions while still young, then seem to suffer a deadline in their powers as they move into adolescence?'. Indeed, our finding verifies the argument that children have a natural curiosity and this curiosity should be fostered (FISHER, 2003, p. 27; 2005, p. 63, 182). 
introducing a philosophical discussion in your classroom: an example of a community of enquiry in a greek primary school

\section{Are students engaged in the community of enquiry?}

The engagement in a community of enquiry was measured by looking for several indicators during the sessions. These indicators can evaluate whether the $\mathrm{P} 4 \mathrm{C}$ is practiced successfully in the classroom.

Take part in the dialogue. For a successful community of enquiry we initially reassured that all the students expressed their opinion. According to the recorded material of the sessions, it was estimated that each student expressed his/her opinion at least once in each session. In the dialogic process, the students should listen to the opinions expressed by their classmates. However, 'philosophical discussions [...] are not opinion surveys'. (MASCITELLI-MOREY, 2013, p. 74). Thus, we also focused on whether the students were listening while their classmates were talking. Fisher (2005) argued that in P4C sessions disconnected answers are sometimes provided due to the anticipation of the students to express their own opinion. In this classroom the students sometimes used the phrases 'I agree' or 'I disagree' linking their answers with what the previous student has just said. Thus, we suggest that the students were listening actively to their classmates. This is verified by the fact that all the students modified their answers after the sessions. The modification of the students' replies at the end of the sessions demonstrates that they possibly listened to at least some of the opinions expressed during the dialogue.

Justify. Although the supporters of Piaget uphold the opinion that children in primary school usually are not developmentally ready for logical reasoning, justification is another form of reasoning which can be used by children (THOMAS, 1992, p. 98). The students in the classroom used the justification in the majority of their replies. The facilitator motivated them to provide a solid reasoning to support their opinion. The students justified their opinions and provide reasons and examples from their experience. This is a promising finding for a future implementation of philosophical enquiry in the classroom. During the P4C sessions in this classroom, the justification was not qualitatively evaluated concerning how strong were their arguments. Nevertheless, the students kept the voted principle of justification by using reasoning linking words in their 
discourse. Last but not least, these research results are in agreement with the results of a small-scale experimental study (GASPARATOU; KAMPEZA, 2012) with a control group (15 students in each group) in a Greek kindergarten. During the study of Gasparatou and Kampeza (2012), the markers that the students used in the sessions were explored. The 'because' was the marker found to be in use the most from the experimental group. This indicates adoption and expansive use of justification in the P4C sessions with young students.

Ask questions. Fisher (2005) has categorised the questions that children ask to five categories; questions that focus attention, force comparison, seek clarification, invite further enquiry and seek reasons or explanation. In this research the students did not set any particular questions which could promote the philosophical enquiry. All of the questions that were set during each session were asking for clarification for a part of the book or sought for an explanation for a previously mentioned opinion. None of the questions led to further enquiry. However, when the students were asked to propose questions for following sessions, they were able to make valid suggestions. It possibly demands more time than four sessions for the students to naturally generate new questions which promote the dialogue during the $\mathrm{P} 4 \mathrm{C}$ sessions.

Define the main concept and search for criteria. Two ways to turn a simple discussion into a philosophical discussion are exploring to define concepts and set objective criteria (BASSIRI; VAIDYA, 2013). We used these two characteristics as a unified indicator, because the definition of a concept is sometimes closely related to the set criteria. Specifically, in the case of these sessions the students defined the person who has been fulfilled by describing Big O. Furthermore, they expressed criteria that they considered necessary to achieve fulfilment, such as effort, confidence and an intrinsic motivation and desire to become independent. These criteria also helped them to define the fulfilled person.

\section{Do students enjoy P4C sessions and what improvements they might suggest?}

To evaluate the process, students were asked to complete an open-ended questionnaire. This is a direct way of the students. All of them agreed that they 
introducing a philosophical discussion in your classroom: an example of a community of enquiry in a greek primary school

enjoyed their participation in the $\mathrm{P} 4 \mathrm{C}$ sessions. This is in line with the results from previously conducted research in Northern Ireland which investigated the perceptions of 364 students and 19 teachers who participated in a sub-category of P4C (DUNLOP; COMPTON; CLARKE; MCKELVEY-MARTIN, 2015). It is worth noting that the conducted interviews with 16 teenagers in Greece after P4C sessions also assign positive feedback (GASPARATOU; ERGAZAKI, 2015).

When students asked what they enjoyed more, they mentioned the lack of the demand for providing right answers. P4C sessions are based on the notion that there is no right or wrong answer. This is one of the main beliefs that educators and students tend to have about P4C sessions, but the opinion of Gazzard (2012, p. 52) 'Some answers are simply and plainly wrong, some are better than others' could be a particular interesting response to this view.

For the improvement of the process, the participating students did not make any suggestions. Probably the duration of the intervention was insufficient for them to identify essential deficiencies or express criticism. Even though a study on P4C suggests that the students recommended improvements concerning their inclusion or the development of co-operation in the community (REZNITSKAYA; GLINA, 2013), the only recommendation made by the students participating in our study involved the selection of the topic of the dialogue. The teacherresearcher chose the book and therefore she chose the topic in advance. In the future they would like to choose the topic in advance and then the teacher would try to find a book related to that topic to stimulate a discussion. This means that an untrained to P4C classroom can gradually process from the structure lesson plan which Wartenberg (2009) suggests to more liberal discussion.

\section{Can P4C sessions cause a change at the students' opinion on a topic?}

Comparing the students' replies between pre-tests and post-tests, an essential modification can be highlighted. At the pre-tests the students (except two of them) argued that Mr Complete is the one who fulfils his tasks successfully and effectively. Furthermore, the drawing at the pre-tests indicates that all the students 
depicted Mr Compete as a circle character6 ${ }^{6}$ In the post-tests, the students defined fulfilment as a process towards independence, autonomy and self-cognition. One of the students argued that fulfilment is a process of maturity, which entails moving towards a different direction, but not always towards a better direction. Only one of the students provided a relatively simplistic answer stating that a fulfilled person does not ask for help to complete a task.

The analysis of the content of the students' replies between pre-tests and post-tests demonstrates that all the students modified their answers. In the posttests the replies were longer and more elaborated. Students changed their definition of 'fulfilment'. Additionally, some of the answers in the post-tests were abstract. Although these findings cannot lead to a generalisable conclusion, they provide with some evidence to support that the students can improve their understanding of the concept and express their opinion differently after participating in P4C sessions. Furthermore, this change could be an indirect indicator that the students were even passively engaged in the philosophical enquiry. Nevertheless, the modification of the expressed opinion following the P4C session does not imply permanent modification or a change that could be reflected on the students' actions.

\section{limitations}

This research uses a small non-representative sample of a particular population and, therefore, the results of the research cannot be generalised to a broader population. Moreover, even though the design was experimental, there was no comparison group to establish a solid causal relationship. It was found that the participants elaborated their views and some of them defined the concept of fulfilment abstractly after the P4C sessions, but as there is a lack of control group it cannot be confirmed whether this change in the opinion is more radical compared to a discussion on a traditional classroom setting.

\footnotetext{
${ }^{6}$ This is not a surprising finding, as circle and mandala have always been identified as the symbols of wholeness throughout the history (JAFFE, 1964, p. 240).
} 
introducing a philosophical discussion in your classroom: an example of a community of enquiry in a greek primary school

Further, it is accepted that the observed increased levels of engagement might not be due to the philosophical intervention itself, but it might be solely a Hawthorne effect (TOGERSON; TOGERSON, 2008, p. 60). In other words, the increased interest of students might result just from the fact that the typical teaching techniques changed. Any change in the routine might cause an interest at the beginning independently of the intervention. This possibility cannot be excluded as it was a short-term intervention.

In addition, this research does not present evidence to support that $\mathrm{P} 4 \mathrm{C}$ sessions result in the enhancement of cognitive or non-cognitive skills. However, in order to address this issue, some large-scale experimental studies could be considered. There is a recent randomised - in a school level - control trial with 3,159 participants Years 4 and 5 in England which found that after two years interventions of $\mathrm{P} 4 \mathrm{C}$, there were small gains in reading and mathematics in Key Stage 2 (GORARD, SIDDIQUI; SEE, 2015). Another experimental study which demonstrated emotional gains after 7 months of P4C intervention (TRICKEY; TOPPING, 2006). Finally, a longitudinal study with experimental design in two private schools near Madrid (COLOM; MORIYON; MAGRO; MORILLA, 2014) shows that after 20 years of intervention cognitive abilities and reasoning development and a small effect size on non-cognitive abilities were reported for the experimental group.

\section{conclusions}

This study is one of the few studies to describe the involvement of Greek students in P4C sessions. This research can be supportive for educators who pursue an understanding of easily implemented formative assessment practices and indicators of engagement in $\mathrm{P} 4 \mathrm{C}$ sessions. In this paper the structure of a $\mathrm{P} 4 \mathrm{C}$ session when it is initially implemented in an untrained classroom was presented. There is a structured lesson plan and a pre-decided topic. The session could gradually be transformed from a precise well-planned discussion to a more liberal dialogue in a community of enquiry. Our method is an example of a study which accepts a constructivistic approach and builds on the students' experience. 
The students in our sample were actively engaged in $\mathrm{P} 4 \mathrm{C}$ sessions by arguing and justifying their opinions. Moreover, the topics that the participating Greek students considered as alluring for future philosophical exploration were presented. The attention is drawn to the investigation of the fluency and the elaboration of the answers of students before and after the dialogue and their comparison. As P4C sessions do not have clear learning goals, the assessment of the elaboration on the opinion focusing on the topic itself before and after the sessions has been mainly neglected in P4C studies. However, through the participation in a community of enquiry, the students enriched their prior experience and modified the way they expressed their opinion.

\section{references}

BASSIRI, A; VAIDYA, A. J. (2013). Making Everyday Discussions More Philosophical. In Implementing Philosophy in Elementary Schools: The Washington Elementary School Philosophy Project. (pp.48-59). Bloomington: Authorhouse.

COHEN, L., MANION, L.; MORRISON, K. (2007). Research methods in education (6 $^{\text {th }}$ edn). Abingdon: Routledge.

COLOM, R. MORIYON, F. MAGRO, C.; MORILLA, E. (2014). The Long-term Impact of Philosophy for Children: A Longitudinal Study (Preliminary Results). Analytic Teaching and Philosophical Praxis, 35(1), 50-56.

DUNLOP, L., COMPTON, K., CLARKE, L.; MCKELVEY- MARTIN, V. (2015) Child-led enquiry in primary science, Education 3-13, 43(5), 462-481. doi:10.1080/03004279.2013.822013.

FISHER, R. (2003). Teaching Thinking. 2nd edn. London and New York: Continuum. FISHER, R. (2005). Teaching children to think. $2^{\text {nd }}$ edn. United Kingdom: Nelson Thornes

GASPARATOU, R.; ERGAZAKI, M. (2015). Students' Views about their Participation in a Philosophy Program. Creative Education, 6, 726-237.

GASPARATOU, R.; KAMPEZA, M. (2012) Introducing P4C in Kindergarten in Greece. Analytic Teaching and Philosophical Praxis, 33(1), 72-82

GAZZARD, A. (2012). Do you Need to Know Philosophy to Teach Philosophy to Children? A Comparison of Two Approaches, Analytic Teaching and Philosophical Praxis, 33(1), 45-53

GORARD, S. (2013). Research Design: Creating Robust Approaches for the Social Sciences. Thousand Oaks, CA: SAGE.

GORARD, S., SIDDIQUI, N.; SEE, B.H. (2015). Philosophy for Children: Evaluation Report and Executive Summary. Retrieved from https://educationendowmentfoundation.org.uk/uploads/pdf/Philosophy_for_C hildren.pdf (access at: 1 November 2015)

HAYNES, J. (2008). Children as philosophers. London: Routledge. 
introducing a philosophical discussion in your classroom: an example of a community of enquiry in a greek primary school

HAYNES, J.; MURRIS, K. (2012) Picturebooks, Pedagogy and Philosophy. London: Routledge.

JAFFE, A. (1964), Symbolism in the visual arts. In: JUNG, C. (ed.) Man and his symbols (pp. 232-270). United States: Anchor Press

KENNEDY, D. (2004). The Philosopher as Teacher: The role of a Facilitator in a Community of Philosophical Inquiry. Metaphilosophy, 35(5), 744-765.

KITCHENER, R. (1990) ‘Do Children Think Philosophically?' Metaphilosophy, 21(4): 427-438.

LIPMAN, M. (1988). Philosophy Goes to School. Philadelphia: Temple University Press.

LIPMAN, M. (1992). On Writing a Philosophical Novel. In: SHARP, A.M.; REED, R.F. (eds.) Studies in Philosophy for Children: Harry Stottlemeier's Discovery (pp.3-7). Philadelphia: Temple University Press.

LIPMAN, M. (2003). Thinking in education (2nd edn). Cambridge \& New York: Cambridge University Press.

LIPMAN, M. (2009). Philosophy for Children: Some Assumptions and Implications. In MARSAL, Eva; DOBASHI, Takara; WEBER, Barbara (eds.), Children Philosophize Worldwide. Frankfurt: Peter Lang.

MASCITELLI-MOREY, S. (2013). Assessing the Effectiveness of Classroom Sessions. In Implementing Philosophy in Elementary Schools: The Washington Elementary School Philosophy Project. (pp. 69-77). Bloomington: Authorhouse.

MATTHEWS, G. B. (1976). Philosophy and Children's Literature. Metaphilosophy 7 (1), 7-16.

MERTENS, D. M. (2010). Research and evaluation in education and psychology. CA: SAGE.

MURRIS, K. (1992). Teaching philosophy with picturebooks. London: Infonet Publications.

PUTNAM, H. (1978). Meaning and the Moral Sciences. London: Routledge and Kegan Paul.

REZNITSKAYA, A.; GLINA, M. (2013). Comparing Student Experiences with Story Discussions in Dialogic Versus Traditional Settings, The Journal of Educational Research, 106(1), 49-63, DOI: 10.1080/00220671.2012.658458.

RUSSELL, B. (1959). The Problems of Philosophy. New York Oxfod University Press

SAPERE: Philosophy for Children, Colleges, Communities (2015). P4C Training Courses. Available at: http:/ / www.sapere.org.uk/Default.aspx?tabid=238 (access: 20th February 2016)

SHARP, M.A. (1992). A Letter to a Novice Teacher: Teaching Harry Stottlemeier's Discovery. In SHARP, A.M. and REED, R.F. (ed.) Studies in Philosophy for Children: Harry Stottlemeier's Discovery (pp. 165-172). Philadelphia: Temple University Press. STEVENS, S.S. (1935). The Operational Basis of Psychology. The American Journal of Psychology, 47 (2), 323-330.

THOMAS, J. C. (1992). The development of Reasoning in Children through Community of Inquiry. In SHARP, A.M. and REED, R.F. (eds) Studies in Philosophy 
for Children: Harry Stottlemeier's Discovery (pp. 96-104). Philadelphia: Temple University Press.

TOGERSON, D.J.; TOGERSON, C.J. (2008). Designing Randomised trials in health, education and social sciences: an introduction. New York: Palgrave Macmillan.

TRICKEY, S.; TOPPING, K.J. (2006). Collaborative Philosophical Enquiry for School Children: Socio-emotional effects at 11 to 12 Years. School Psychology International, 27(5), 599-614.

WARTENBERG, T. E. (2009). Big Ideas for Little Kids. Plymouth, UK: Rowman \& Littlefield Publishers, Inc.

WARTENBERG, T.E. (2014). Assessing an Elementary School Philosophy Program. Thinking: The Journal of Philosophy for Children, 20 (3-4), 90-94.

Received in: 10.08.2016

Accepted in: 14.09.2016 